\title{
Attitudes of women in Cambodia towards child physical abuse
}

\section{[version 1; peer review: 2 approved with reservations]}

\section{Koustuv Dalal (iD)1,2, Reshma Parvin Nuri (D)3, Ming Shinn Lee, (D)4, Chao Kuang Lin5, Mervyn Gifford6, Gainel Ussatayeva1 ${ }^{1}$, Animesh Biswas (iD) 7}

\author{
${ }^{1}$ Higher School of Public Health, Al-Farabi Kazakh National University, Almaty, Kazakhstan \\ 2Department of Public Health Science, School of Health and Education,, University of Skövde, Skövde, Skövde, Sweden \\ ${ }^{3}$ Queen's University, Kingston, Ontario, Canada \\ ${ }^{4}$ National Dong Hwa University, Hualien, Taiwan \\ ${ }^{5}$ Education Center for Humanities and Social Sciences, National Yang-Ming University, Taipei, Taiwan \\ ${ }^{6}$ School of Health Science, Örebro University, Örebro, Sweden \\ ${ }^{7}$ Department of Reproductive and Child Health, Centre for Injury Prevention and Research, Bangladesh (CIPRB), Dhaka, 1206, \\ Bangladesh
}

\author{
V1 First published: 29 Nov 2018, 7:1866 \\ https://doi.org/10.12688/f1000research.16489.1 \\ Latest published: 29 Nov 2018, 7:1866 \\ https://doi.org/10.12688/f1000research.16489.1
}

\begin{abstract}
Background: This study attempted to explore the women's attitude towards child physical abuse in relation to the respondent's background factors, personal issues and autonomy.

Methods: This was a cross-sectional study of 18,749 women of reproductive age (15-49 years) using 2010 Cambodia Demographic and Health Survey. Chi-square tests and bivariate analyses were performed.
\end{abstract}

Results: A significant proportion of women supported beating physically abusing sons (69.2\%) and daughters (67.2\%). Rural, nonBuddhist, those with no or primary education, poverty, seasonal or occasional employment seem to be risk factor for supporting child physical abuse by women (in bivariate analysis). Age, education and household economic status of the women are significantly relevant for child physical abuse (in bivariate analysis). Women who came from male-headed households more often supported beating their children. Female autonomy is an important factor for child physical abuse. Women who justify physical abuse towards wives were also generally supportive of child physical abuse.

Conclusions: The current study provides knowledge about maternal factors such as age, education, economic status, rural/urban dwelling, two or more lifetime partners and autonomy in the supporting of beating sons and daughters. Further attention needs to be paid to increasing women's education and autonomy in Cambodian family life.

\section{Keywords}

children, abuse, physical punishment, autonomy, mother, Cambodia

\section{Open Peer Review \\ Approval Status ? ? \\ 12 \\ version 1

$?$
view \\ 1. Mina Golestani, Tabriz University of Medical Sciences, Tabriz, Iran \\ 2. John D Melville, Medical University of South Carolina, Charleston, USA \\ Any reports and responses or comments on the article can be found at the end of the article.}


Corresponding author: Animesh Biswas (ani72001@gmail.com)

Author roles: Dalal K: Conceptualization, Formal Analysis, Methodology, Validation, Visualization, Writing - Original Draft Preparation, Writing - Review \& Editing; Parvin Nuri R: Writing - Original Draft Preparation, Writing - Review \& Editing; Shinn Lee, M: Methodology, Writing - Original Draft Preparation; Kuang Lin C: Methodology, Writing - Original Draft Preparation; Gifford M: Methodology, Writing Original Draft Preparation, Writing - Review \& Editing; Ussatayeva G: Methodology, Writing - Original Draft Preparation; Biswas A: Methodology, Writing - Original Draft Preparation, Writing - Review \& Editing

Competing interests: No competing interests were disclosed.

Grant information: The author(s) declared that no grants were involved in supporting this work.

Copyright: ( 2018 Dalal K et al. This is an open access article distributed under the terms of the Creative Commons Attribution License, which permits unrestricted use, distribution, and reproduction in any medium, provided the original work is properly cited.

How to cite this article: Dalal K, Parvin Nuri R, Shinn Lee, M et al. Attitudes of women in Cambodia towards child physical abuse [version 1; peer review: 2 approved with reservations] F1000Research 2018, 7:1866 https://doi.org/10.12688/f1000research.16489.1

First published: 29 Nov 2018, 7:1866 https://doi.org/10.12688/f1000research.16489.1 


\section{Introduction}

Child abuse is a major public health problem ${ }^{1}$. Child abuse is now alarmingly widespread in East Asia and the Pacific region, and it has immediate, long lasting and devastating effects on children ${ }^{2}$. Among other forms of abuse, physical abuse is more common among Asian and Pacific families than families from other parts of the world ${ }^{3-5}$. The overall prevalence rates of physical abuse range from 10 to $30.3 \%$ in the East Asia region. Boys are more exposed of physical abuse than girls, which can include physical punishment and severe physical contact violence ${ }^{2}$. In Cambodia over half of all children have experienced physical abuse ${ }^{6}$.

Both abuse and neglect negatively affect the development of a child's brain 7 . It is well established that physical abuse has negative impact on physical, psychological and social and behavioral health of children ${ }^{8}$. This can ultimately affect the child's long-term health-related quality of life and lead to problems such as depression, substance abuse, anxiety and suicidal behavior, increased risk of sexually transmitted diseases, and even cancer $^{9-12}$. Adolescents who have been physically abused are more likely to show increased of externalizing problems and criminal offending ${ }^{13,14}$. In addition, adolescents and adults who had experienced physical and/or sexual abuse in their childhood are four times more likely to have suicidal ideation, than their peers who had not experienced such abuses ${ }^{2}$. Furthermore, among adults who had been physically abused as children there is a higher degree of aggression compared with adults who had not been abused ${ }^{13,14}$. Physical punishment of children are very frequent in East Asia and the Pacific region including Cambodia $^{2}$. A study of low- and middle-income countries indicated that more than half of children were subjected to some kind of violent physical punishment, as the adults believe that such physical abuses of the children are not harmful ${ }^{15}$. However, the experts have strongly argued that child physical punishment such as beating should not be believed to be a minor form of physical abuse, as it causes several physical and psychological health problems ${ }^{16}$.

Many studies have explored the parental risk factors of child abuse. Such risk factors include poverty, low family income and socioeconomic status. Lower level of parental education, large families, younger parental age, substance abuse and mental illness in parents are also contributing factors of child abuse. Adults having been maltreated in their childhood, intimate partner violence, parents' divorce, or violence between other family members are identified risk factors for child abuse $\mathrm{s}^{1,4,13,17}$. Furthermore, low parental self-esteem, depression, psycho-pathology, and social isolation are also positively related to child physical abuse $^{18,19}$. Moreover, a recent study suggested that men who abused their wives were also frequently abusive to their children ${ }^{20}$. Therefore, parents' background and personal experiences can influence the likelihood of child abuse. However, we have no specific information how Cambodian parents are perpetrating, though child abuse prevalence is very high ${ }^{2,16}$. African studies and Indian study have indicated that autonomy is important factor for child abuse, while we have no information from Cambodia ${ }^{1,16,18}$. Therefore, in this context, considering the mother's role within family and towards her children, the current study has focused on women's background factors, personal issues and autonomy for household decision-making in relation to child physical abuse.

It has been narrated that mothers are twice more likely to psychologically or physically abuse their children than fathers ${ }^{21}$. Cambodian refugee mothers in America who suffered from depression frequently abused their children ${ }^{22}$. Previous research found that maternal stress has a direct role in the physical abuse of children ${ }^{23}$. Another study conducted among Korean immigrant mothers found that the amount of time spent with children, experience of corporal punishment as a child, children's gender and age, family acculturation conflicts, mothers' age, and length of time in US are the macro-level variables that affect Korean immigrant mothers' attitudes toward child physical abuse ${ }^{24}$. Existing studies of abusing Cambodian children are mainly focused on immigrant families in high income countries. To better understand the situation, a national representative study is highly warranted ${ }^{1}$. Cambodia has a very high prevalence of child physical abuse, including child punishment at home. UNICEF has strongly advocated for preventing child abuse at home $^{16}$. Women are leading factors in household issues, especially in Southeast Asian countries, such as Cambodia. However, to our knowledge, no research has been conducted to reveal women's attitude towards child abuse at home in Cambodia ${ }^{4}$. Therefore, the objective of this study was to explore women's attitude towards child physical abuse in relation to the respondent's background factors, personal issues and autonomy.

\section{Methods}

The study employed 2010 Cambodia Demographic and Health Survey (CDHS-2010) data ${ }^{25}$. In total, 18,749 women of reproductive age (15-49 years) were interviewed between 23 July 2010 and 20 January 2011 in 19 national sampling domains throughout Cambodia (14 individual provinces: Banteay Mean Chey, Kampong Cham, Kampong Chhnang, Kampong Speu, Kampong Thom, Kandal, Kratie, Phnom Penh, Prey Veng, Pursat, Siem Reap, Svay Rieng, Takeo, and Otdar Mean Chey. Five groups of provinces: Battambang and Pailin, Kampot and Kep, Preah Sihanouk and Koh Kong, Preah Vihear and Steung Treng, and Mondol Kiri and Rattanak Kiri).

The sampling frame used two stratified stages (more details available in CDHS-2010) $)^{25}$. Initially, stratification was made by separating 19 domains into urban and rural areas. Then from each of 19 sampling domains one rural area and one urban area were considered totaling 38 sampling strata. Initially, from these 38 sampling strata, 611 enumeration areas (EAs) were selected with a probability proportional to size (PPS) based on the 2008 Cambodia General Population Census. In total, 191 EAs from the urban areas, and 420 EAs from the rural areas were selected. Each household was then listed within each selected EA. From the list, 24 households in each urban EA and 28 households in each rural EA were randomly selected, totaling, 16,344 households.

However, 15,829 households had potential respondents during data collection. In these households 19,237 women of reproductive age (15-49 years) who were the usual residents 
of the selected households, or visitors who had spent the previous night before the survey, were identified as being eligible for individual interview. Finally, 18,749 women responded to the interview questionnaires (response rate $97.5 \%$ ).

In total, 109 field staff received 22 days training and 4 days field practice. Each field team was comprised of a team leader, a field editor, three female interviewers, and one male interviewer. Data processing personnel had three data processing supervisors, 10 office editors/coders, 19 data entry operators. In total 37 data entry staff had received necessary classroom training. To minimize data entry error, all questionnaires were entered twice in to the data entry system.

\section{Variables of interest}

In the survey, three questions were asked regarding the women respondents' justification towards parental beating of sons and three questions addressed the parental beating of daughters. "In your opinion, is a parent justified in hitting or beating his son/ daughter for the following reasons:

i) disobeying them: yes/no

ii) being impolite: yes/no

iii) doing something embarrassing to the family: yes/no

In the current study, main variables were constructed merging all three reasons "justified beating of son by parents" and "justified beating of daughter by parents".

As independent variables, respondents background factors, personal issues and their autonomy issues are considered in the study. Background factors include: age (seven age groups: 15-19, 20-24, 25-29, 30-34, 35-39, 40-45 and 45-49 years); residency (rural/urban); religion (Buddhist/non-Buddhist); education (No-education, primary, secondary and higher); economic status (poorest, poorer, middle, richer and richest); employment status (all round the year, seasonal and occasional) and sex of household head (female or male) and if the respondent was covered by health insurance (yes/no). Personal issues of the respondents consisted of eight variables: exposure to media, such as reading newspapers, listening to radio or watching television (yes/no); sons/daughters who lived at home; sons/ daughters who have died; husband lived with the respondent (living with her/lives elsewhere); justified wife beating (yes/no); number of partners (one/two or more). Autonomy of the respondents was measured by five questions: Who decided on spending money; decision making on healthcare; decision making on large household purchases; decision making on visits to family or relatives; decision making on what to do with the money the husband earns. All questions have had three options: respondent alone; respondent and husband/partner jointly or partner or other person without the respondent.

\section{Statistical analyses}

We used proportions and chi-squared tests to explore the cross relationships between attitudes towards beating sons/daughters and the independent variables. Bivariate logistic regressions were performed to study the potential associations between the justification of child beating by parents and the respondents' socioeconomic factors, personal issues and autonomy. IBM SPSS version 22 was used for the data analysis.

\section{Ethical issues}

This study used secondary data and hence does not need any ethical permission.

\section{Results}

Of the 18,749 participants, a significant proportion of women supported physically abusing sons and daughters (69.2\% and $67.2 \%$ ). There is an association between age and supporting beating children. Women who lived in rural area, who had no education, and who were poorest, most often supported beating sons and daughters $(\mathrm{p}<0.001)$. This was also more prevalent among non-Buddhist women. In addition, full- or part-time employment of women was associated with supporting beating sons and daughters $(p<0.001)$. Finally, women who came from male-headed households more often supported beating their children (Table 1).

Support for beating sons and daughters was more prevalent among those parents for whom health care service costs were covered by insurance $(\mathrm{p}<0.001)$. A higher proportion of women who had no exposure to media supported beating sons and daughters. A signification proportion of women with at least one dead son/daughter supported beating children. In addition, a higher proportion of women who justified wife beating more often supported beating their child $(\mathrm{p}<0.001)$. Finally, women who had two or more lifetime partners more often supported beating sons and daughters $(\mathrm{p}<0.001)($ Table 2$)$.

A significant proportion of women who could not make decisions about their own healthcare, large household purchases, visits to family or relatives or how to spend their husband's money most often supported beating sons and daughters $(\mathrm{p}<0.001)$ (Table 3).

\section{Multivariate analyses}

Compared with the oldest age group, women between 20-34 years were more likely to support beating sons and daughters. Uneducated mothers were more likely to support beating of sons (odds ratio (OR) 2.8187, CI 1.936-4.099; $\mathrm{P}<0.0001$ ) and to support beating daughters (OR 2.644, CI 1.825-3.829; $\mathrm{P}<0.0001)$ compared to higher educated women. In addition, compared with the richest women, the poorest mothers were more likely to support child beating (son: OR 1.53, CI 1.205-1.943; daughter: OR 1.432, CI 1134-1.809). Moreover, women who did not justify wife beating were less likely to support child beating (son: OR 0.194, CI 0.172-0.219; daughter: OR 0.206, CI 0.184-0.232). Furthermore, women who had the autonomy to take decision about their own healthcare, visiting family or relatives, and on spending husbands' money were less likely to support beating sons and daughters $(\mathrm{p}<0.0001)$ (Table 4).

\section{Discussion}

This study investigated women's attitudes towards child physical abuse by parents in relation to the women's background factors, personal issues and autonomy. The current work provides 

Table 1. Background factors of the respondent women who supported beating of
sons and daughters.

\begin{tabular}{|c|c|c|c|c|c|}
\hline \multirow[t]{2}{*}{ Variables } & \multirow[t]{2}{*}{$\mathbf{N}$} & \multicolumn{2}{|c|}{$\begin{array}{l}\text { Supported beating } \\
\text { sons }\end{array}$} & \multicolumn{2}{|c|}{$\begin{array}{l}\text { Supported beating } \\
\text { daughters }\end{array}$} \\
\hline & & $\%(n)$ & $P$ value & $\%(n)$ & $P$ value \\
\hline Age, years & & & 0.03 & & .009 \\
\hline $15-19$ & 3914 & $70.7(2767)$ & & $68.6(2686)$ & \\
\hline $20-24$ & 3170 & $67.3(2133)$ & & $65.1(2063)$ & \\
\hline $25-29$ & 3209 & $68.1(2186)$ & & 66.0 (2119) & \\
\hline 30-34 & 2178 & $70.0(1526)$ & & $68.7(1496)$ & \\
\hline 35-39 & 1993 & $70.4(1403)$ & & $68.4(1364)$ & \\
\hline $40-44$ & 2225 & $69.4(1545)$ & & $68.1(1515)$ & \\
\hline $45-49 y$ & 2060 & $68.3(12967)$ & & $66.2(1364)$ & \\
\hline Residence & & & $<0.001$ & & $<0.001$ \\
\hline Urban & 6073 & $60.6(3681)$ & & $59.0(3587)$ & \\
\hline Rural & 12673 & 73.3 (9286) & & $71.2(9020)$ & \\
\hline Religions & & & $<0.001$ & & $<0.001$ \\
\hline Buddhist & 17794 & $68.8(12250)$ & & $66.8(11895)$ & \\
\hline Non Buddhist & 955 & $75.1(717)$ & & $74.6(712)$ & \\
\hline Education & & & $<0.001$ & & $<0.001$ \\
\hline No-education & 3203 & $77.2(2474)$ & & $76(2433)$ & \\
\hline Primary & 8792 & 73.6 (6469) & & 71.6 (6296) & \\
\hline Secondary & 6140 & $62.2(3819)$ & & $59.9(3679)$ & \\
\hline Higher & 614 & $33.4(205)$ & & 32.4 (199) & \\
\hline Economic status & & & $<0.001$ & & $<0.001$ \\
\hline Poorest & 3259 & $77.4(2521)$ & & $75.8(2471)$ & \\
\hline Poorer & 3159 & $76.0(2401)$ & & 74.0 (2339) & \\
\hline Middle & 3240 & $73.1(2367)$ & & 70.6 (2287) & \\
\hline Richer & 3734 & $70.0(2615)$ & & $67.6(2526)$ & \\
\hline Richest & 5357 & $57.2(3063)$ & & $55.7(2984)$ & \\
\hline Employment status & & & $<0.001$ & & $<0.001$ \\
\hline All year & 7019 & $62.7(4404)$ & & $60.6(4255)$ & \\
\hline Seasonal & 7472 & $76.5(5713)$ & & $74.5(5567)$ & \\
\hline Occasional & 523 & 76.3 (399) & & $75.1(393)$ & \\
\hline Sex of household head & & & $<0.001$ & & $<0.001$ \\
\hline Male & 14232 & $69.7(9916)$ & & $68.0(9673)$ & \\
\hline Female & 4517 & $67.5(3051)$ & & $65.0(2934)$ & \\
\hline Covered by health insurance & & & $<0.001$ & & $<0.001$ \\
\hline No & 16196 & $68.0(11017)$ & & $66.0(10686)$ & \\
\hline Yes & 2552 & $76.4(1950)$ & & $75.3(1921)$ & \\
\hline
\end{tabular}




\begin{tabular}{|c|c|c|c|c|c|}
\hline \multirow[t]{2}{*}{ Variables } & \multirow[t]{2}{*}{$\mathbf{N}$} & \multicolumn{2}{|c|}{$\begin{array}{l}\text { Supported beating } \\
\text { sons }\end{array}$} & \multicolumn{2}{|c|}{$\begin{array}{l}\text { Supported beating } \\
\text { daughters }\end{array}$} \\
\hline & & $\%$ & $P$ value & $\%$ & $P$ value \\
\hline Media Exposure & & & $<0.001$ & & $<0.001$ \\
\hline No & 2161 & $77.5(1675)$ & & $76.1(1645)$ & \\
\hline Yes & 16588 & $68.1(11292)$ & & $66.1(10962)$ & \\
\hline Sons at home & & & $<0.001$ & & $<0.001$ \\
\hline No & 10084 & $67.8(6840)$ & & $65.8(6632)$ & \\
\hline Yes & 8665 & 70.7 (6127) & & $69.0(5975)$ & \\
\hline Daughters at home & & & $<0.001$ & & $<0.001$ \\
\hline No & 10197 & $67.6(6891)$ & & $65.4(6672)$ & \\
\hline Yes & 8552 & $71.0(6076)$ & & $69.4(5935)$ & \\
\hline Sons who have died & & & $<0.001$ & & $<0.001$ \\
\hline No & 17077 & $68.7(11740)$ & & $66.8(11409)$ & \\
\hline At least one son died & 1672 & $73.4(1227)$ & & $71.7(1198)$ & \\
\hline Daughters who have died & & & $<0.001$ & & $<0.001$ \\
\hline No & 17332 & $68.8(11922)$ & & $66.9(11587)$ & \\
\hline At least one daughter died & 1417 & $73.7(1045)$ & & $72.0(1020)$ & \\
\hline Husband lives in house & & & 0.18 & & 0.03 \\
\hline Living with her & 11008 & $70.3(7738)$ & & $68.4(7532)$ & \\
\hline Staying elsewhere & 520 & $73.1(380)$ & & $72.9(375)$ & \\
\hline Justified wife beating & & & $<0.001$ & & $<0.001$ \\
\hline No & 9626 & $52.5(5058)$ & & 50.6 (4869) & \\
\hline Yes & 9119 & 86.7 (7908) & & $84.9(7737)$ & \\
\hline Number of partner/s & & & $<0.001$ & & $<0.001$ \\
\hline One life time partner & 11833 & $69.8(8257)$ & & $67.9(8036)$ & \\
\hline Two or more lifetime partners & 1003 & $75.5(757)$ & & $74.4(746)$ & \\
\hline
\end{tabular}

some new insight in the research concerning the women's demographic factors and supporting beating sons and daughters.

The study found that a significant proportion of women supported beating sons and daughters, and that it was more prevalent among uneducated rural dwellers and the poorest mothers. Women who came from male-headed households more often supported beating their children. Women without media exposure proportionally experienced more physical violence than their peers with media exposure. The first group of women (without media exposure) supports more child physical abuse than the other group (with media exposure). Also, women having two or more lifetime partners more often supported beating sons and daughters.
Previous literature demonstrates a robust connection between poverty and child physical abuse ${ }^{26}$. The current study also has same findings. Compared with other factors, poverty and low socioeconomic status is consistently associated with child maltreatment and the most severe abuse cases were found among the poorest people ${ }^{27,28}$. We have found that younger women were more likely to support beating children than older women. In addition, younger parental age, low education, and parental physical-mental health are significant predictors of child maltreatment ${ }^{29}$. The results of a previous study indicates that families with low socioeconomic status or lower level of income, parental mental illness augments the risk of child abuse and maltreatment ${ }^{30}$. Our findings have supported the same results in the context of Cambodia. It was also found that mental stress 


\begin{tabular}{|c|c|c|c|c|c|}
\hline \multirow[t]{2}{*}{ Variables } & \multicolumn{3}{|c|}{ Supported beating sons } & \multicolumn{2}{|c|}{$\begin{array}{l}\text { Supported beating } \\
\text { daughters }\end{array}$} \\
\hline & $\mathbf{n}$ & $\%$ & $P$ value & $\%$ & $P$ value \\
\hline Who decides how to spend money & & & 0.74 & & 0.27 \\
\hline Respondent alone & 4,867 & $67.8(3,301)$ & & $65.4(3,183)$ & \\
\hline Respondent and husband/partner & 2,368 & $68.5(1,622)$ & & $66.9(1,585)$ & \\
\hline Partner/other person & 123 & $65.9(81)$ & & $61.8(76)$ & \\
\hline Final say on own health care & & & $<0.001$ & & $<0.001$ \\
\hline Respondent alone & 4,736 & $68.8(3,258)$ & & $67.5(3,199)$ & \\
\hline Respondent and husband/partner & 5,727 & $69.5(3,981)$ & & $67.2(3,851)$ & \\
\hline Partner/other person & 1,070 & $82.3(881)$ & & $80.7(863)$ & \\
\hline Final say on making large household purchases & & & $<0.001$ & & $<0.001$ \\
\hline Respondent alone & 1,728 & $75.6(1,306)$ & & $73.6(1,271)$ & \\
\hline Respondent and husband/partner & 9,180 & $68.6(6,293)$ & & $66.9(6,137)$ & \\
\hline Partner/other person & 625 & $83.4(521)$ & & $80.8(505)$ & \\
\hline Final say on visits to family or relatives & & & $<0.001$ & & $<0.001$ \\
\hline Respondent alone & 2,525 & $74.1(1,870)$ & & $71.5(1,806)$ & \\
\hline Respondent and husband/partner & 8,425 & $69.1(5,822)$ & & $67.5(5,689)$ & \\
\hline Partner/other person & 583 & $73.4(428)$ & & $71.7(418)$ & \\
\hline $\begin{array}{l}\text { Final say on deciding what to do with money } \\
\text { husband earns }\end{array}$ & & & $<0.001$ & & $<0.001$ \\
\hline Respondent alone & 5,928 & $69.6(4,123)$ & & $67.7(4,013)$ & \\
\hline Respondent and husband/partner & 4,960 & $70.6(3,501)$ & & $68.9(3,415)$ & \\
\hline Partner/other person & 598 & $78.1(467)$ & & $76.4(457)$ & \\
\hline
\end{tabular}

because of inadequate housing, overcrowding, lack of social support, and social isolation all increase the risk of abuse among Cambodian refugee families in America $^{4}$. Poor families face challenges in providing adequate child care and supervision.

Although most of the previous studies found little differences in child abuse incidence rates between urban and rural areas, we found that women who live in rural areas supported beating their children more than in urban areas ${ }^{22-24,31}$. Similarly, another study found that physical and sexual abuse was common among rural dwellers than non-rural dwellers in the $\mathrm{USA}^{32}$.

The present study indicates that women's higher education may be a protective factor for child physical abuse, which is contrary to the existing research, where higher parental education was a risk factor for child physical abuse ${ }^{13}$. Previous studies also indicated that lack of income to meet the family's needs as well as no or lower education augments the risk of child physical abuse in both low- and high-income countries ${ }^{33,34}$.

We also found that women who experience physical violence more often supported child beating. Previous studies indicated that domestic violence (DV) enhances the risk of child physical abuse $\mathrm{e}^{17,31}$. There is evidence that exposure to physical DV is independently associated with an increased risk of mothers using violent methods to correct child behavior ${ }^{1}$. Children from families with a history of DV are at increased risk of physical abuse, resulting a cycle of violence between spouse and child physical abuse ${ }^{31,35}$.

This study found in the bivariate analysis that women who came from male-headed households often supported beating their child. In the logistic regression this was not significant. Similarly, a prior study found that the rate of female-headed households was negatively associated with abuse rates in African American neighborhoods ${ }^{36}$.

The results of this study indicate that increased autonomy for women in relation to their own health care and permitting visiting family or relatives and spending husband's money may reduce son and daughter beating. In fact, World Health Organization (WHO) violence prevention meetings have highlighted female empowerment as a way of tackling violence within the family $^{37}$. Our study has added materials in to that WHO call ${ }^{37}$ 


\begin{tabular}{|c|c|c|c|c|c|c|}
\hline \multirow[t]{2}{*}{ Variables } & \multicolumn{3}{|c|}{ Supported beating sons } & \multicolumn{3}{|c|}{$\begin{array}{l}\text { Supported beating } \\
\text { daughters }\end{array}$} \\
\hline & ORs & Lower $\mathrm{Cl}$ & Upper Cl & ORs & Lower $\mathrm{Cl}$ & Upper Cl \\
\hline \multicolumn{7}{|l|}{ Age } \\
\hline $15-19$ years & 1.103 & 0.762 & 1.596 & 1.114 & 0.777 & 1.599 \\
\hline 20-24years & $1.501^{* * *}$ & 1.193 & 1.888 & $1.489^{* * *}$ & 1.189 & 1.865 \\
\hline 25-29years & $1.372^{\star \star \star}$ & 1.128 & 1.669 & $1.336^{* \star *}$ & 1.103 & 1.619 \\
\hline 30-34years & $1.381^{\star * *}$ & 1.127 & 1.691 & $1.383^{\star * *}$ & 1.133 & 1.688 \\
\hline 35-39years & $1.316^{* *}$ & 1.072 & 1.615 & $1.284^{* *}$ & 1.05 & 1.57 \\
\hline 40-44years & 1.143 & 0.937 & 1.394 & 1.149 & 0.945 & 1.396 \\
\hline 45-49year & Ref. & & & Ref. & & \\
\hline \multicolumn{7}{|l|}{ Residence } \\
\hline Urban & 1.114 & 0.962 & 1.29 & 1.12 & 0.97 & 1.294 \\
\hline Rural & Ref. & & & Ref. & & \\
\hline \multicolumn{7}{|l|}{ Religions } \\
\hline Buddhist & 1.232 & 0.885 & 1.716 & 1.19 & 0.858 & 1.65 \\
\hline Non Buddhist & Ref. & & & Ref. & & \\
\hline \multicolumn{7}{|l|}{ Education } \\
\hline No-education & $2.817^{\star \star *}$ & 1.936 & 4.099 & $2.644^{* * *}$ & 1.825 & 3.829 \\
\hline Primary & $2.518^{* * *}$ & 1.778 & 3.566 & $2.237^{\star * *}$ & 1.585 & 3.157 \\
\hline Secondary & $1.861^{* * *}$ & 1.321 & 2.622 & $1.662^{* * *}$ & 1.184 & 2.334 \\
\hline Higher & Ref. & & & Ref. & & \\
\hline \multicolumn{7}{|c|}{ Sex of household head } \\
\hline Male & 1.091 & 0.946 & 1.258 & 1.12 & 0.97 & 1.294 \\
\hline Female & Ref. & & & Ref. & & \\
\hline \multicolumn{7}{|c|}{ Economic status } \\
\hline Poorest & $1.53^{\star * *}$ & 1.205 & 1.943 & $1.432^{* * *}$ & 1.134 & 1.809 \\
\hline Poorer & $1.468^{* * *}$ & 1.178 & 1.829 & $1.364^{* * *}$ & 1.1 & 1.691 \\
\hline Middle & $1.296^{\star *}$ & 1.061 & 1.584 & $1.253^{\star *}$ & 1.029 & 1.525 \\
\hline Richer & 1.413 & 1.194 & 1.672 & $1.374^{* * *}$ & 1.164 & 1.622 \\
\hline Richest & Ref. & & & Ref. & & \\
\hline \multicolumn{7}{|c|}{ Employment status } \\
\hline All year & 0.872 & 0.601 & 1.263 & 0.792 & 0.55 & 1.143 \\
\hline Seasonal & 0.88 & 0.605 & 1.279 & 0.788 & 0.545 & 1.14 \\
\hline Occasional & Ref. & & & Ref. & & \\
\hline \multicolumn{7}{|c|}{ Covered by health insurance } \\
\hline No & 0.929 & 0.775 & 1.115 & 1.033 & 0.917 & 1.165 \\
\hline Yes & Ref. & & & Ref. & & \\
\hline \multicolumn{7}{|c|}{ Media Exposure } \\
\hline No & 1.024 & 0.841 & 1.247 & 1.064 & 0.878 & 1.289 \\
\hline Yes & Ref. & & & Ref. & & \\
\hline \multicolumn{7}{|l|}{ Sons at home } \\
\hline No & Ref. & & & Ref. & & \\
\hline Yes & 0.976 & 0.863 & 1.104 & 0.994 & 0.881 & 1.122 \\
\hline
\end{tabular}




\begin{tabular}{|c|c|c|c|c|c|c|}
\hline \multirow[t]{2}{*}{ Variables } & \multicolumn{3}{|c|}{ Supported beating sons } & \multicolumn{3}{|c|}{$\begin{array}{l}\text { Supported beating } \\
\text { daughters }\end{array}$} \\
\hline & ORs & Lower Cl & Upper Cl & ORs & Lower Cl & Upper Cl \\
\hline \multicolumn{7}{|l|}{ Daughters at home } \\
\hline No & Ref. & & & Ref. & & \\
\hline Yes & 1.002 & 0.887 & 1.133 & 1.033 & 0.917 & 1.165 \\
\hline \multicolumn{7}{|l|}{ Sons who have died } \\
\hline No & Ref. & & & Ref. & & \\
\hline At least one son died & 1.009 & 0.842 & 1.208 & 0.98 & 0.822 & 1.168 \\
\hline \multicolumn{7}{|l|}{ Daughters who have died } \\
\hline No & Ref. & & & Ref. & & \\
\hline At least one daughter died & 1.027 & 0.845 & 1.247 & 1.039 & 0.859 & 1.257 \\
\hline \multicolumn{7}{|l|}{ Husband lives in house } \\
\hline Living with her & Ref. & & & Ref. & & \\
\hline Staying elsewhere & 1.075 & 0.814 & 1.419 & 1.274 & 0.968 & 1.679 \\
\hline \multicolumn{7}{|l|}{ Justified wife beating } \\
\hline No & $0.194^{\star * *}$ & 0.172 & 0.219 & $0.206^{* * *}$ & 0.184 & 0.232 \\
\hline Yes & Ref. & & & Ref. & & \\
\hline \multicolumn{7}{|l|}{ Number of partner } \\
\hline One life time partner & Ref. & & & Ref. & & \\
\hline Two or more lifetime partner & 1.045 & 0.843 & 1.295 & 1.114 & 0.902 & 1.376 \\
\hline \multicolumn{7}{|l|}{ Decision on spending money } \\
\hline Respondent alone & Ref. & & & Ref. & & \\
\hline Respondent and husband/partner & 0.893 & 0.765 & 1.044 & 0.985 & 0.846 & 1.146 \\
\hline Partner/other person & 0.635 & 0.393 & 1.028 & 0.664 & 0.416 & 1.06 \\
\hline \multicolumn{7}{|l|}{ Deciding on own health care } \\
\hline Respondent alone & Ref. & & & Ref. & & \\
\hline Respondent and husband/partner & $1.186^{\star *}$ & 1.043 & 1.349 & 1.07 & 0.943 & 1.214 \\
\hline Partner/other person & $1.752^{* * *}$ & 1.352 & 2.27 & $1.628^{\star \star *}$ & 1.268 & 2.09 \\
\hline \multicolumn{7}{|l|}{$\begin{array}{l}\text { Deciding on making large household } \\
\text { purchases }\end{array}$} \\
\hline Respondent alone & Ref. & & & Ref. & & \\
\hline Respondent and husband/partner & $0.797^{\star *}$ & 0.667 & 0.953 & $0.819^{* *}$ & 0.688 & 0.975 \\
\hline Partner/other person & 0.929 & 0.622 & 1.388 & 0.737 & 0.507 & 1.071 \\
\hline \multicolumn{7}{|l|}{$\begin{array}{l}\text { Deciding on visiting family or } \\
\text { relatives }\end{array}$} \\
\hline Respondent alone & Ref. & & & Ref. & & \\
\hline Respondent and husband/partner & 0.915 & 0.789 & 1.062 & 1 & 0.865 & 1.156 \\
\hline Partner/other person & $0.615^{\text {*** }}$ & 0.445 & 0.851 & 0.709 & 0.517 & 0.974 \\
\hline \multicolumn{7}{|l|}{ Deciding on husband's money } \\
\hline Respondent alone & Ref. & & & Ref. & & \\
\hline Respondent and husband/partner & $1.43^{* * *}$ & 1.222 & 1.675 & $1.367^{* * *}$ & 1.172 & 1.595 \\
\hline Partner/other person & $1.477^{\star *}$ & 1.02 & 2.139 & $1.441^{* *}$ & 1.005 & 2.066 \\
\hline
\end{tabular}

Reference categories are denoted as Ref. ${ }^{* * *} \mathrm{p}<0.001$; ${ }^{* *} \mathrm{p}<0.01$. 
for women empowerment extending the protective factor from DV to child abuse. However, the current study along with other reproductive age group, includes young women aged 15-19 years who are still regarded as minors in many countries. In Cambodia, girls are often married early. In Cambodia, the majority of the teenaged girls have household autonomy such as own monetary spending, health care, visiting friends/relatives and a level of control over husband/partners income ${ }^{25}$. Previous studies found that maternal stress, psychopathology and depression are closely linked with child abuse ${ }^{26,37}$. Less autonomy increases maternal stress which in turn increases the likelihood of child physical abuse. There is evidence that personal autonomy and social capital reduces the onset of depression in women, which ultimately reduces child abuse ${ }^{38}$.

Compared to other national surveys, the CDHS has some important advantages. CDHS is nationally representative; therefore, findings and conclusions are applicable to the whole of Cambodia. CDHS, like other DHS studies, has high response rates. CDHS has used very high-quality interviewer training and standardized data collection procedures. The sampling methodology is well tested in Cambodia and in other low and middle income countries. The study has some limitations. DHS data from many countries advocate that DHS surveys underestimate the extent of violence and abuse. On the other hand, other surveys like multi-country surveys from WHO or UNICEF better estimate the extent of violence and abuse ${ }^{39}$. Therefore, the current findings might underestimate the extent of violence and abuse. In many cases, more than one respondent from the same household was interviewed. However, each respondent was interviewed separately and privately to minimize response bias $^{31}$. The cross-sectional analysis does not allow for causal inference. Therefore, the current study is suffering from the same problem indicating the necessity of longitudinal studies to firmly establishing the causality. This study contributed to the literature by identifying relevant women's characteristics in relation to attitude towards child physical abuse. Fathers' characteristics were not assessed in this study. Future studies may include fathers in order to make a full evaluation of familial disciplinary attitudes and behaviors. Also, qualitative studies exploring the attitude towards child physical abuse could be of interest.

The current work provides knowledge about maternal factors such as age, education, economic status, rural/urban dwelling, two or more lifetime partners and autonomy in the supporting of beating sons and daughters. Further attention needs to be paid to increasing women's education and autonomy in their family life in Cambodia.

\section{Data availability}

Data for this study were obtained from the DHS Program (Cambodia: Standard DHS, 2010). Access to the dataset requires registration, and is granted to those that wish to use the data for legitimate research purposes. A guide for how to apply for dataset access is available at: https://dhsprogram.com/data/ Access-Instructions.cfm.

\section{Grant information}

The author(s) declared that no grants were involved in supporting this work.
1. Dalal k, Lawoko S, Jansson B: The relationship between intimate partner violence and maternal practices to correct child behavior: a study on women in Egypt. J Inj Violence Res. 2010; 2(1): 25-33.

PubMed Abstract | Publisher Full Text | Free Full Text

2. UNICEF: A statistical snapshot on child abuse in East Asia and the Pacific. 2012; cited 2017 Dec 5.

Reference Source

3. Chang J, Rhee S, Weaver D: Characteristics of child abuse in immigrant Korean families and correlates of placement decisions. Child Abuse Negl. 2006; 30(8): 881-891.

PubMed Abstract | Publisher Full Text

4. Chang J, Rhee S, Berthold SM: Child abuse and neglect in Cambodian refugee families: characteristics and implications for practice. Child Welfare. 2008; 87(1): 141-60. PubMed Abstract

5. Zhai F, Gao Z: Child maltreatment among Asian Americans: characteristics and explanatory framework. Child Maltreat. 2009; 14(2): 207-24. PubMed Abstract | Publisher Full Text

6. Ministry of women's affairs(MOWA), UNICEF Cambodia, US Centers for Disease Control and Prevention: Findings from Cambodia's violence against children survey 2013. Cambodia: ministry of women's affairs, 2014. Reference Source

7. Perry BD: The neurodevelopmental impact of violence in childhood. In Schetky D, Benedek EP(Ed). Textbook of child and adolescent forensic psychiatry. Washington DC: American psychiatric risk of mother-reported child abuse in the first three years of life. Child abuse and neglect; 2001.

Reference Source
8. Corcoran J: Family interventions with child physical abuse and neglect: a critical review. Child Youth Serv Rev. 2000; 22(7): 563-591. Publisher Full Text

9. Draper B, Pfaff JJ, Pirkis J, et al.: Long-term effects of childhood abuse on the quality of life and health of older people: results from the Depression and Early Prevention of Suicide in General Practice Project. J Am Geriatr Soc. 2008; 56(2): 262-271.

PubMed Abstract | Publisher Full Text

10. Jewkes RK, Dunkle K, Nduna M, et al:: Associations between childhood adversity and depression, substance abuse and HIV and HSV2 incident infections in rural South African youth. Child Abuse Negl. 2010; 34(11): 833-41. PubMed Abstract | Publisher Full Text | Free Full Text

11. Norman RE, Byambaa M, De R, et al.: The long-term health consequences of child physical abuse, emotional abuse, and neglect: a systematic review and meta-analysis. PLoS Med. 2012; 9(11): e1001349.

PubMed Abstract | Publisher Full Text | Free Full Text

12. Fuller-Thomson E, Brennenstuhl S: Making a link between childhood physical abuse and cancer: results from a regional representative survey. Cancer. 2009; 115(14): 3341-50.

PubMed Abstract | Publisher Full Text

13. Lueger-Schuster B, Knefel M, Glück TM, et al.: Child abuse and neglect in institutional settings, cumulative lifetime traumatization, and psychopathological long-term correlates in adult survivors: The Vienna Institutional Abuse Study. Child Abuse Negl. 2018; 76: 488-501. PubMed Abstract | Publisher Full Text

14. World Health Organization: Preventing child maltreatment: a guide to action and generating evidence. Geneva: world health organization and international society 
for prevention of child abuse and neglect; 2006. Reference Source

15. Straus M, Gelles R, Steinmetz S: Physical violence in the American family. Beverly Hills, CA: Sage Publications. 1990; 622 Reference Source

16. UNICEF: Child disciplinary practices at home: evidence from a range of lowand middle-income countries. UNICEF: New York, 2010

Reference Source

17. Straus MA: Beating the devil out of them: corporal punishment by parents and its effects on children. New york: Lexington books. 1994; 297. Reference Source

18. Zhu Y, Dalal K: Childhood exposure to domestic violence and attitude towards wife beating in adult life: a study of men in India. J Biosoc Sci. 2010; 42(2): 255-69.

PubMed Abstract | Publisher Full Text

19. Stoltenborgh M, Bakermans-Kranenburg MJ, van ljzendoorn $\mathrm{MH}$ : The neglect of child neglect: a meta-analytic review of the prevalence of neglect. Soc Psychiatry Psychiatr Epidemiol. 2013; 48(3): 345-55 PubMed Abstract | Publisher Full Text | Free Full Text

20. Chan KL, Brownridge DA: Personality characteristics of Chinese male batterers: an exploratory study of women's reports from a refuge sample of battered women in Hong Kong. Am J Mens Health. 2008; 2(3): 218-28. PubMed Abstract | Publisher Full Text

21. Al Dosari MN, Ferwana M, Abdulmajeed I, et al: Parents' perceptions about child abuse and their impact on physical and emotional child abuse: A study from primary health care centers in Riyadh, Saudi Arabia. J Family Community Med. 2017; 24(2): 79-85 PubMed Abstract | Free Full Text

22. Chan KL: Co-occurrence of intimate partner violence and child abuse in Hong Kong Chinese families. J Int Per Viol. 2011; 26(7): 1322-1342. PubMed Abstract | Publisher Full Text

23. Douki ZE, Esmaeili MR, Vaezzadeh N, et al:: Maternal child abuse and its association with maternal anxiety in the socio-cultural context of iran. Oman Med J. 2013; 28(6): 404-409.

PubMed Abstract | Publisher Full Text | Free Full Text

24. Park MS: The factors of child physical abuse in Korean immigrant families. Child Abuse Negl. 2001; 25(7): 945-58. PubMed Abstract | Publisher Full Text

25. CDHS. 2010. cited 2018 Jan 7. Reference Source

26. Hahm HC, Lee Y, Ozonoff Al, et al:: The impact of multiple types of child maltreatment on subsequent risk behaviors among women during the transition from adolescence to young adulthood. J Youth Adolesc. 2010; 39(5): 528-540. PubMed Abstract | Publisher Full Text | Free Full Text

27. Fourth National Incidence Study of Child Abuse and Neglect (NIS-4): Report to
Congress. 2010. cited 2017 Nov 26.

Reference Source

28. Bywaters $\mathrm{P}$, Bunting $\mathrm{L}$, Davidson $\mathrm{G}$, et al:: The relationship between poverty, child abuse and neglect: an evidence review. York: Joseph Rowntree Foundation. 2016 Reference Source

29. Holt S, Buckley $\mathrm{H}$, Whelan S: The impact of exposure to domestic violence on children and young people: a review of the literature. Child Abuse Negl. 2008; 32(8): 797-810

PubMed Abstract | Publisher Full Text

30. Prinz RJ: Parenting and family support within a broad child abuse prevention strategy: Child maltreatment prevention can benefit from public health strategies. Child Abuse Negl. 2016; 51: 400-406.

PubMed Abstract | Publisher Full Text | Free Full Text

31. Dalal K, Lindqvist K: A national study of the prevalence and correlates of domestic violence among women in India. Asia Pac J Public Health. 2012; 24(2): 265-77.35.

PubMed Abstract | Publisher Full Text

32. Freisthler B, Merritt DH, LaScala EA: Understanding the ecology of child maltreatment: a review of the literature and directions for future research. Child Maltreat. 2006; 11(3): 263-80. PubMed Abstract | Publisher Full Text

33. Isaranurug $S$, Nitirat $P$, Chauytong $P$, et al.: Factors relating to the aggressive behavior of primary caregiver toward a child. J Med Assoc Thai. 2001; 84(10): 1481-1489. PubMed Abstract

34. Dalal K, Rahman F, Jansson B: The origin of violent behaviour among child labourers in India. Glob Public Health. 2008; 3(1): 77-92.

PubMed Abstract | Publisher Full Text

35. Straus M, Gelles R, Steinmetz S, et al.: Behind closed doors. Garden City, Ny: Anchor Press. 1980.

36. Garbarino J, Kostelny K: Child maltreatment as a community problem. Child Abuse Negl. 1992; 16(4): 455-464

PubMed Abstract | Publisher Full Text

37. WHO: Inspire: Seven Strategies For Ending Violence Against Children. Geneva: WHO. 2016.

Reference Source

38. Bojorquez-Chapela I, Manrique-Espinoza BS, Mejía-Arango S, et al:: Effect of social capital and personal autonomy on the incidence of depressive symptoms in the elderly: evidence from a longitudinal study in Mexico. Aging Ment Health. 2012; 16(4): 462-71. PubMed Abstract | Publisher Full Text

39. Corsi DJ, Neuman M, Finlay JE, et al:: Demographic and health surveys: a profile. Int J Epidemiol. 2012; 41(6): 1602-13.

PubMed Abstract | Publisher Full Text 


\section{Open Peer Review}

\section{Current Peer Review Status: ? ?}

\section{Version 1}

Reviewer Report 03 July 2020

https://doi.org/10.5256/f1000research.18023.r66337

(C) 2020 Melville J. This is an open access peer review report distributed under the terms of the Creative Commons Attribution License, which permits unrestricted use, distribution, and reproduction in any medium, provided the original work is properly cited.

\section{John D Melville}

Division of Child Abuse Pediatrics, Medical University of South Carolina, Charleston, SC, USA

The work presents a cross sectional study of attitudes of Cambodian women regarding corporal punishment.

A few criticisms:

1. The question asked, when translated into English, combines both "hitting" and "beating" which, at least in the American South, considers different degrees of severity. It is unclear to me what behaviors the women considered to be acceptable.

2. The risk factors identified reflect well known risk factors for physical discipline, and the ORs are quite modest. Many of these small distinctions are statically significant due to the large sample size.

3. The reporting of the logistic regression is unclear. The methods section describes "bivariate logistic regression" which in the results section is titled "multivariate analysis." Logistic regression can be used for both bivariate and multivariate analysis but the interpretation of the resulting numbers is very different. The article should clarify how the analysis was performed.

4. The second paragraph of the introduction has little relevance to the paper presented and should be omitted.

5. A somewhat surprising statement: "It has been narrated that mothers are twice more likely to psychologically or physically abuse their children than fathers" is cited to Al Dosari (2017). Upon reviewing the cited paper it is not immediately clear that the citation supports the claim.

6. The authors suggest that increasing female autonomy will decrease child physical abuse. While this may be true, it is inappropriate to infer causation in a cross-sectional survey such as this one. 
In summary this paper reports a secondary analysis of a significant effort to survey a representative sample of Cambodian women. The article is of limited significance, only because the results are strongly concordant with prior research. The paper could be improved with a better description of the multivariate analysis and a more focused hypothesis and conclusion.

Is the work clearly and accurately presented and does it cite the current literature? Yes

Is the study design appropriate and is the work technically sound?

Yes

Are sufficient details of methods and analysis provided to allow replication by others? Yes

If applicable, is the statistical analysis and its interpretation appropriate? Partly

Are all the source data underlying the results available to ensure full reproducibility? Yes

Are the conclusions drawn adequately supported by the results? No

Competing Interests: No competing interests were disclosed.

Reviewer Expertise: Child Abuse Pediatrics

I confirm that I have read this submission and believe that I have an appropriate level of expertise to confirm that it is of an acceptable scientific standard, however I have significant reservations, as outlined above.

Reviewer Report 07 October 2019

https://doi.org/10.5256/f1000research.18023.r54537

(C) 2019 Golestani M. This is an open access peer review report distributed under the terms of the Creative Commons Attribution License, which permits unrestricted use, distribution, and reproduction in any medium, provided the original work is properly cited.

\section{Mina Golestani}

Road Traffic Injury Research Center, Tabriz University of Medical Sciences, Tabriz, Iran

It seems very important to choose the subject of child abuse and research in this area; in this way, a few items seemed vague that needed correction:

1. It's not better to look at social status or relationships with friends in relation to confounding factors. It also seems to be effective in child abuse. 
2. In Table 2, the authors noted that "media exposure" had a significant relationship with the child abuse. Please explain this clearly.

3. The authors stated that "families with daughters/sons who died" supported beating the child - this is due to many factors regardless of the cause of the child's loss. Please explain the reason for this in the paper.

Is the work clearly and accurately presented and does it cite the current literature? Yes

Is the study design appropriate and is the work technically sound?

Yes

Are sufficient details of methods and analysis provided to allow replication by others? Yes

If applicable, is the statistical analysis and its interpretation appropriate?

Yes

Are all the source data underlying the results available to ensure full reproducibility? Partly

Are the conclusions drawn adequately supported by the results?

Yes

Competing Interests: No competing interests were disclosed.

Reviewer Expertise: Injury research, of course I have also published an article in this area

I confirm that I have read this submission and believe that I have an appropriate level of expertise to confirm that it is of an acceptable scientific standard, however I have significant reservations, as outlined above. 
The benefits of publishing with F1000Research:

- Your article is published within days, with no editorial bias

- You can publish traditional articles, null/negative results, case reports, data notes and more

- The peer review process is transparent and collaborative

- Your article is indexed in PubMed after passing peer review

- Dedicated customer support at every stage

For pre-submission enquiries, contact research@f1000.com 